\title{
Exposure to environmental tobacco smoke and respiratory tract infections in pre-school children - a cross-sectional study in Poland
}

\author{
Dorota Emilia Bielska', Donata Kurpas², Aneta Nitsch-Osuch ${ }^{3}$, Ewa Gomółka ${ }^{4}$, Elżbieta Ołdak ${ }^{5}$, \\ Sławomir Chlabicz', Anna Owłasiuk' ${ }^{1}$ \\ ${ }^{1}$ Department of Family Medicine and Community Nursing, Medical University, Bialystok, Poland \\ ${ }^{2}$ Department of Family Medicine, Medical University, Wroclaw, Poland \\ ${ }^{3}$ Family Medicine Department, Medical University, Warsaw, Poland \\ ${ }^{4}$ Department of Clinical Toxicology and Environmental Disease, Jagiellonian University Collegium Medicum, Cracow, Poland \\ ${ }^{5}$ Department of Pediatric Infectious Diseases, Medical University, Bialystok, Poland
}

Bielska DE, Kurpas D, Nitsch-Osuch A, Gomółka E, Ołdak E, Chlabicz S, Owłasiuk A. Exposure to environmental tobacco smoke and respiratory tract infections in pre-school children - a cross-sectional study in Poland. Ann Agric Environ Med. 2015 ; 22 (3): 524-529. doi: $10.5604 / 12321966.1167728$

\begin{abstract}
Introduction and objective. Knowledge of the harmful influence of environmental tobacco smoke (ETS) has a positive impact on changing social behaviours worldwide. In many homes smoking is totally prohibited; in some others, partial limitations of tobacco consumption have been introduced.

Objective. To study the correlation between the adopted rules of tobacco use in homes of 3-year-olds, and the kind and frequency of acute respiratory system infections within a 6-month period of attending pre-schools.

Materials and methods. The study was performed among children attending municipal pre-schools in Białystok, Poland. The data was collected by anonymous questionnaires completed by the parents of 302 children aged 3 years chosen randomly from 1,200 children attending 51 pre-schools. The exposure of children to tobacco smoke was measured by determining cotinine to creatinine ratio (CCR) in urine.

Results. In the 150 families of children who were surveyed, 210 were smokers. Every day, the smokers consisted of fathers (37.3\%) and mothers (23.6\%). The 3-year-old children were divided into 3 groups according to smoking habits in their homes: $28.5 \%$ of the children under examination came from homes where tobacco smoking was forbidden (mean CCR - 15.21ng/ $\mathrm{mg}, \mathrm{SD}=11.86$ ), 26.2\% came from homes where tobacco was smoked in separate rooms (mean CCR $-65.75 \mathrm{ng} / \mathrm{ml}, \mathrm{SD}=81.51$ ), 45.4\% lived in homes where no rules connected with smoking had been established (mean CCR $-61.75 \mathrm{ng} / \mathrm{ml}, \mathrm{SD}=70.29$ ). During the analyzed period of 6 months, $85 \%$ of the children had at least 1 respiratory tract infection (60\% - upper, $16.9 \%$ - lower, $16.5 \%$ - upper and lower, $7.1 \%$ - otitis media).

Conclusions. The majority of the 3-year-old children who had lower respiratory tract infections required antibiotics and hospitalization. Living in a home where no tobacco rules were established may cause an increase of respiratory tract infections.
\end{abstract}

- Key words

children, respiratory tract infections, tobacco smoke pollutions

\section{INTRODUCTION}

Acute respiratory system diseases in pre-school children are a significant problem in the practice of a GP, especially when the infections are recurrent. The moment of first contact with infectious factors in a large group of children is often the turning point in a child's medical history, but the kind and frequency of respiratory system infections are influenced by various endo- and exogenous factors. Tobacco smoke is one of the main elements of indoor air pollution, and is a factor inducing and modifying the course of respiratory system diseases $[1,2]$. It is highlighted in literature that children of parents who smoke are grow up in worse living conditions and become ill more frequently, compared to their peers not exposed to environmental tobacco smoke $[3,4]$.

Currently, $38 \%$ of adult males and $27 \%$ of females in Poland smoke every day; $53 \%$ of citizens are exposed to

Address for correspondence: Dorota Emilia Bielska Department of Family Medicine and Community Nursing UMB, ul. Mieszka I 4B, 15-054 Białystok

E-mail: d.bielska1@wp.pl

Received: 08 January 2013; accepted: 21 December 2013 environmental tobacco smoke (ETS) at home and $40 \%$ at work [5]. Smoking one cigarette in a closed room produces $30.4 \mathrm{mg}$ of dry substance, pollutes $3-4 \mathrm{~m}^{3}$ of space, and $50 \mathrm{~m}^{3}$ of air needs to be exchanged in order to remove the smell [6]. Knowledge about the harmful influence of ETS has a positive impact on changing social behaviours around the world. In many homes smoking is totally prohibited; in some others, partial limitations of tobacco consumption are introduced [7].

\section{OBJECTIVE}

To study the correlation between the adopted rules of tobacco use in homes of 3-year-old children, and the kind and frequency of acute respiratory system infections within a 6-month period of attending pre-schools. The rate of exposure to ETS was measured on the basis of survey data, objectified by determination of a marker of tobacco smoke exposition - cotinine to creatinine ratio (CCR) in urine of the studied children. 


\section{MATERIALS AND METHOD}

3 -year-old children from families living in the city of Białystok, the capital of a province located in north-eastern Poland, with a population of 294,200 people were included in the study [8]. Its total surface area is $102 \mathrm{~km}^{2}$, including $4,1 \%$ of green areas [9]. There are 354.7 cars to every 1,000 residents [10]. On the basis of data from the Provincial Fund for Environmental Protection concerning air cleanliness in Białystok, it was found that the norms of P10 suspended dusts were exceeded ecvery year between 2004-2007, and 2011-2012 (D24=50 $\mu / \mathrm{m}^{3}$ 35days/year); the norms for P2,5, $\mathrm{SO}_{2}, \mathrm{NO}_{2}, \mathrm{CO}, \mathrm{CO}_{2}$ and $\mathrm{O}_{3}$ were not exceeded. [11].

From among the 1,200 children aged 3 years attending 51 municipal pre-schools, 390 were randomly chosen (every third or fourth child from the alphabetic attendance registers).

The study tool was an original survey questionnaire entitled 'The environment of my three-year-old', anonymously filledin by the caregivers of the randomly chosen children. The questionnaire was composed of 3 modules to evaluate the environmental conditions, incidence of respiratory system diseases among the children, and the structure of tobacco use in their families. The module devoted to previous respiratory system diseases included questions referring to the medical history and treatment in the first 3 years of life before attending pre-school and in the period of attending pre-school between January - June 2004.

302 completed questionnaires were received, and 153 girls (50.5\%) and 149 boys (49.5\%) were included in the study.

The exposure of children to tobacco smoke was measured by determining the cotinine to creatinine ratio (CCR) in urine [12]. $15 \mathrm{ml}$ samples of morning urine were obtained from 284 children. Among the received samples, 140 were randomly chosen for determination of cotinine and creatinine concentration. The urine samples were stored at the temperature of $-70^{\circ} \mathrm{C}$. The extraction and quantitative analysis of cotinine was performed by high-performance liquid chromatography method (HPLC). The limits of linearity (LOL) were in the range $5-1,000 \mathrm{ng} / \mathrm{ml}$; limit of determination (LOD) $-3 \mathrm{ng} / \mathrm{ml}$; limit of quantification (LOQ) $-5 \mathrm{ng} / \mathrm{ml}$. The coefficient of variation of cotinine in concentrations 20 and $100 \mathrm{ng} / \mathrm{ml}$ did not exceed $10 \%$ and amounted up to $4.8 \%$ (inter-day CV) and 7.8\% (intra-days CV).

Creatinine was determined by the kinetic colorimetric method with alkaline picrate without deproteinization, with the use of Creatinine kinetic reagent set (CREA) and a biochemistry analyzer (Konelab 60i).

Statistical methods. The obtained results were subject to statistical analysis in which the arithmetic mean, standard deviation (SD), minimum and maximum values were calculated for the measurable features, whereas quantity and percentage distribution was calculated for the non-measurable values.

For the features conforming to normal distribution, evaluated with the Shapiro-Wilk test, the one-way analysis of variance (ANOVA) was applied for comparisons between the analyzed groups, and for the features non-conforming to that distribution, the Kruskal-Wallis test was applied. The qualitative variables between groups were compared with the $\mathrm{Chi}^{2}$ test. For the calculations, the significance level $\mathrm{p}<0.05$ was assumed as statistically significant. The calculations were carried out with the use of the SPSS statistical packet.

\section{RESULTS}

In $47.9 \%$ of the analyzed families (150), 210 smokers were found: $37.3 \%$ were fathers (112), $23.6 \%$ were mothers (71), and 27 other household members (grandfathers, grandmothers, relatives). The fathers smoked 14 cigarettes a day, on average $(\mathrm{SD}=10.23)$, smoking mothers -8 cigarettes, on average $(\mathrm{SD}=8.18)$, and other household members - 15 cigarettes, on average $(\mathrm{SD}=11.14)$.

On the basis of the rules of tobacco use at home provided by the parents, the children were divided into 3 groups:

1. Group 0 (Gr0) - children from families where smoking is totally forbidden

2. Group 1 (Grl) - children from homes where smoking is permitted in separated rooms (kitchen, bathroom or hall).

3. Group 2 (Gr2) - children from homes where there are no rules concerning tobacco use.

The number of children in individual groups and the CCR values are presented in Table 1.

Table 1. Number of children classified according to ETS exposure and CCR values

\begin{tabular}{|c|c|c|c|c|c|c|}
\hline \multirow[b]{2}{*}{ Group } & \multirow{2}{*}{$\begin{array}{l}\text { No. of } \\
\text { children }\end{array}$} & \multicolumn{5}{|c|}{ Cotinine/creatinine (CCR) [ng/mg] } \\
\hline & & $\begin{array}{l}\text { Highest } \\
\text { value }\end{array}$ & $\begin{array}{l}\text { Lowest } \\
\text { value }\end{array}$ & $\begin{array}{l}\text { Mean } \\
\text { value }\end{array}$ & SD & $\begin{array}{c}\text { No. of analyzed } \\
\text { urine samples }\end{array}$ \\
\hline Group 0 & 86 & 45.7 & 0.0 & 15.2 & 11.9 & 43 \\
\hline Group 1 & 79 & 350.3 & 0.5 & 65.8 & 81.5 & 40 \\
\hline Group 2 & 137 & 379.1 & 0.2 & 61.8 & 70.3 & 57 \\
\hline Total & 302 & & & & & 140 \\
\hline $\mathrm{p}$ & & & $\begin{array}{l}\text { Gro } \\
\text { Gro } \\
\text { Gr }\end{array}$ & $\begin{array}{l}\mathrm{Gr} 1 p<0 \\
\mathrm{Gr} 2 p<0 \\
\mathrm{Gr} 2 p=2\end{array}$ & & \\
\hline
\end{tabular}

The groups differed significantly with regards to the parents' level of education, income per person in the family and living conditions.

The highest number of children from $\mathrm{Gr} 0$ and the lowest number of children from Gr2 had parents with higher education. The differences between education levels of parents of children from particular groups were statistically significant (Tab. 2).

Table 2. Educational level of parents in each group of ETS exposure

\begin{tabular}{|c|c|c|c|c|c|c|}
\hline \multirow{2}{*}{ Group } & \multicolumn{3}{|c|}{ Mother's educational level } & \multicolumn{3}{|c|}{ Father's educational level } \\
\hline & higher & secondary & elementary & higher & secondary & elementary \\
\hline \multirow{2}{*}{ Gro } & 54 & 29 & 3 & 43 & 35 & 8 \\
\hline & $62.8 \%$ & $33.7 \%$ & $3.5 \%$ & $50 \%$ & $40.7 \%$ & $9.3 \%$ \\
\hline \multirow{2}{*}{ Gr1 } & 34 & 39 & 6 & 30 & 42 & 7 \\
\hline & $43 \%$ & $49.4 \%$ & $7.6 \%$ & $38.0 \%$ & $53.2 \%$ & $8.9 \%$ \\
\hline \multirow{2}{*}{ Gr2 } & 43 & 88 & 6 & 31 & 89 & 15 \\
\hline & $31.4 \%$ & $64.2 \%$ & $4.4 \%$ & $23.0 \%$ & $65.9 \%$ & $11.1 \%$ \\
\hline \multirow{2}{*}{ Total } & 131 & 156 & 15 & 104 & 166 & 30 \\
\hline & $43.4 \%$ & $51.7 \%$ & $5.0 \%$ & $34.7 \%$ & $55.3 \%$ & $10.0 \%$ \\
\hline \multirow{3}{*}{$p$} & \multicolumn{3}{|c|}{ Gr0-Gr1 p=0.034 } & \multicolumn{3}{|c|}{ Gr0 - Gr1 p=0.25 } \\
\hline & \multicolumn{3}{|c|}{ Gr0-Gr2 p<0.001 } & \multicolumn{3}{|c|}{ Gr0 - Gr2 p<0.001 } \\
\hline & \multicolumn{3}{|c|}{ Gr1-Gr2 p=0.094 } & \multicolumn{3}{|c|}{$\mathrm{Gr} 1-\mathrm{Gr} 2 \mathrm{p}=0.063$} \\
\hline
\end{tabular}

The average annual net income per person amounted to: Gr0 - PLN 12,317 (SD=15.83);

Gr1 - PLN 9,210 (SD=8.31);

$\mathrm{Gr} 2$ - PLN 7,034 (SD=8.66) $(\mathrm{p}=0.008)$. 
526

Annals of Agricultural and Environmental Medicine 2015, Vol 22, No 3

Dorota Emilia Bielska, Donata Kurpas, Anta Nitsch-Osuch, Eva Gomółka, Elżbieta Ołdak, Sławomir Chlabicz, Anna Owłasiuk. Exposure to environmental tobacco smoke...

Most of the studied children - 79.1\% (239) - lived in blocks of flats, $5 \%$ (15) in terraced houses, and $15.9 \%$ (48) in detached houses. In detached houses lived $25.6 \%$ of the children $(22)$ in Gro, $15.2 \%$ (12) in Gr and 10.2\% (14) in Gr; in terraced houses - 7\% (6) in Gro, 1.5\% (1) in Gr1 and 5.8\% (8) in Gr; in blocks of flats $-67.4 \%$ (58) in Gro, 83.5\% (66) in Gre and 83.9\% (115) in Gre (Gro: Gre p=0.008; Gre: Gre p=0.160; Gro: Gro p=0.008).

The average total surface of the flats in which the studied 3-year-olds lived was: Gr0-81.6 m<super>2, Gr1-67.2 m<super>2, Gr$\left.62.5 \mathrm{~m}^{2} \mathrm{p}=0.013\right)$; the average number of $\mathrm{m}^{2}$ in the flat was: Gr0-21,75 (SD=15.83), Gr1-17.67 ( $\mathrm{SD}=8.31)$, Gr2-13.21 $(\mathrm{SD}=8.66),(\mathrm{p}=0.005)$.

During pregnancy, none of the mothers of children from Gro used tobacco products, but $7 \%$ of the fathers smoked. In Gr1-10.1\% of mothers and $47.4 \%$ of fathers smoked, and in Gr2-16.1\% of mothers and $62.8 \%$ of fathers smoked (Tab. 3).

The occurrence of at least one acute respiratory system infection in the subjects over 6 months of attending poreschools was reported by $87.2 \%$ of parents of children from Gro, 78.5\% in Gr1 and 87.6\% in Gr (Tab. 4). The number of acute infections in children from particular studied groups
Table 3. ETS prenatal exposure

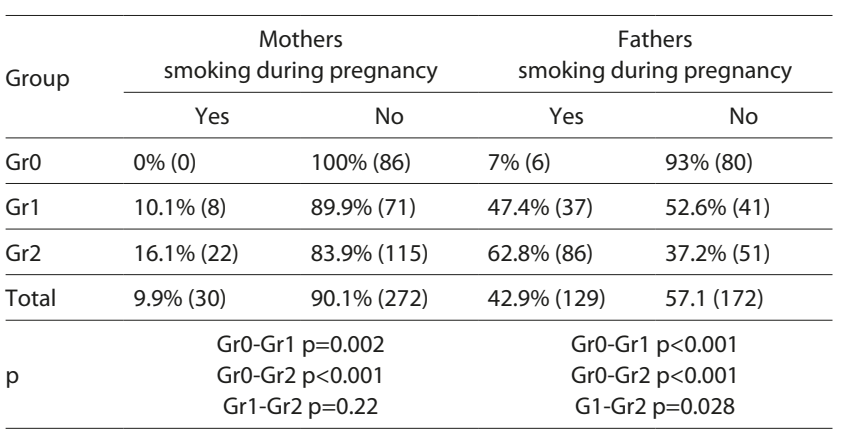

is presented by the following categories: upper respiratory tract infections (acute rhinitis, pharyngitis, laryngitis), lower respiratory tract infections (bronchitis, pneumonia) and otitis media (Tab. 5).

In all the groups, recurrences of acute upper respiratory tract infections prevailed - the biggest number of them occurred in children from $\mathrm{Gr} 2$. Acute lower respiratory tract infections were also the most common among children from

Table 4. Children by frequency of occurrence of acute respiratory tract infections

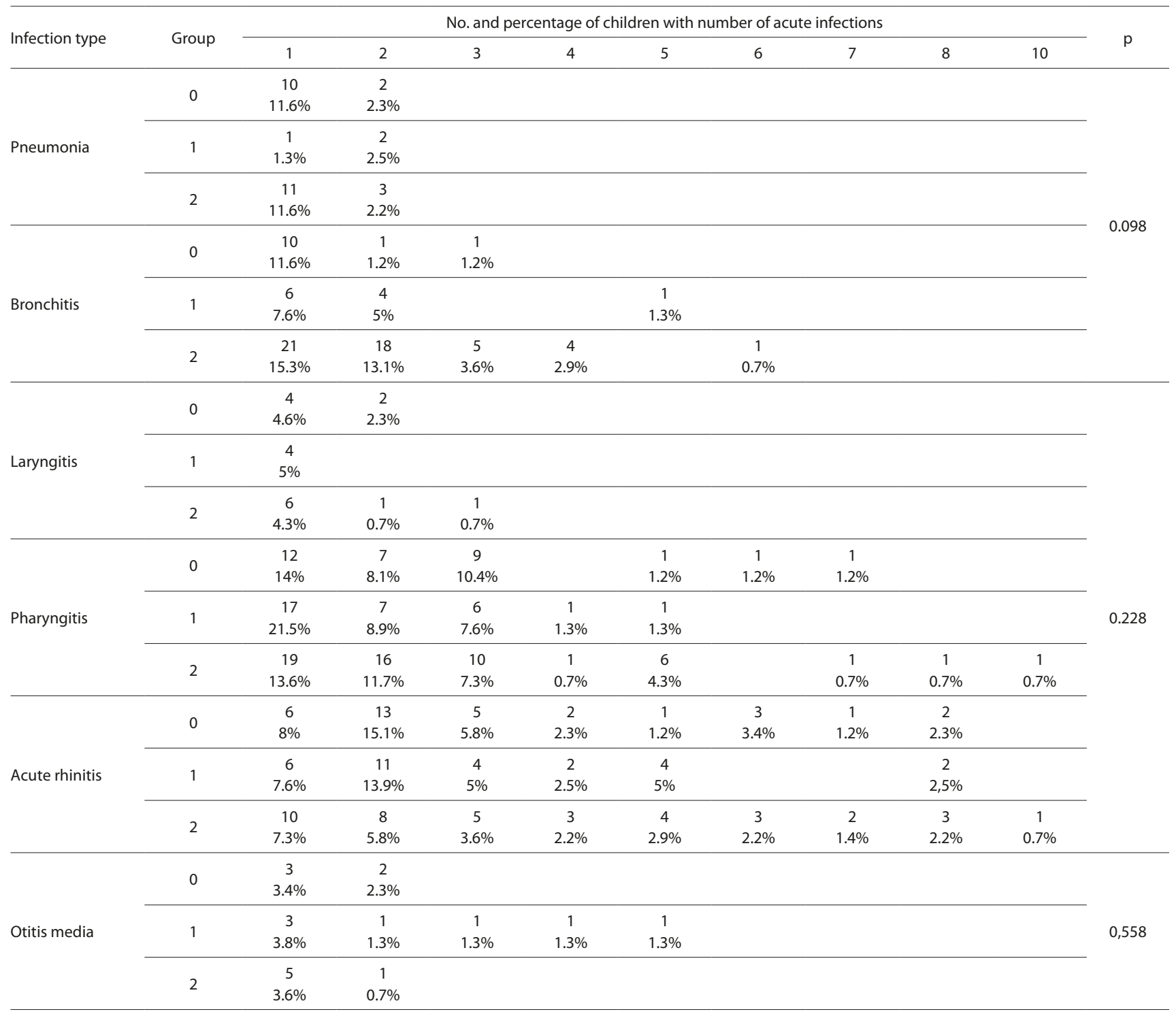


Table 5. Number and percentage of children with frequency of occurrence of acute respiratory tract infections

\begin{tabular}{|c|c|c|c|c|c|c|c|c|c|c|}
\hline \multirow{2}{*}{ Group } & \multirow{2}{*}{ Types of acute respiratory tract infections } & \multicolumn{9}{|c|}{ No. and percentage of children with specific number of acute infections } \\
\hline & & 1 & 2 & 3 & 4 & 5 & 6 & 7 & 8 & 10 \\
\hline \multirow{5}{*}{0} & Infections of lower & 20 & 3 & 1 & & & & & & \\
\hline & Infections of upper & 22 & 22 & 14 & 2 & 2 & 4 & 2 & 2 & \\
\hline & respiratory tract & $25.5 \%$ & $25.5 \%$ & $16.2 \%$ & $2.3 \%$ & $2.3 \%$ & $4.7 \%$ & $2.3 \%$ & $2.3 \%$ & \\
\hline & Otitis & 3 & 2 & & 1 & & & & & \\
\hline & media & $3.4 \%$ & $2.3 \%$ & & $1.2 \%$ & & & & & \\
\hline \multirow{6}{*}{1} & Infections of lower & 7 & 6 & & & 1 & & & & \\
\hline & respiratory tract & $8.9 \%$ & $7.6 \%$ & & & $1.3 \%$ & & & & \\
\hline & Infections of upper & 27 & 18 & 10 & 3 & 5 & 1 & & 2 & \\
\hline & respiratory tract & $34.1 \%$ & $25.3 \%$ & $12.7 \%$ & $3.8 \%$ & $6.3 \%$ & $1.3 \%$ & & $3.8 \%$ & \\
\hline & Otitis & 3 & 1 & 1 & 1 & 1 & & & & \\
\hline & media & $3.8 \%$ & $1.3 \%$ & $1.3 \%$ & $1.3 \%$ & $1.3 \%$ & & & & \\
\hline \multirow{5}{*}{2} & respiratory tract & $23.3 \%$ & $15.3 \%$ & $3.6 \%$ & $2.9 \%$ & & $0.7 \%$ & & & \\
\hline & Infections of upper & 35 & 25 & 26 & 4 & 10 & 3 & 3 & 4 & 2 \\
\hline & respiratory tract & $25.5 \%$ & $18.2 \%$ & $11.7 \%$ & $2.9 \%$ & $7.3 \%$ & $2.1 \%$ & $2.1 \%$ & $2.9 \%$ & $1.5 \%$ \\
\hline & Otitis & 5 & 1 & & & & & & & \\
\hline & media & $3.6 \%$ & $0.7 \%$ & & & & & & & \\
\hline
\end{tabular}

Gr2, whereas they were least frequently found in children from Grl. Between the number of children in Group 1 and 2 who had up to 4 lower respiratory tract infections within 6 months, statistically significant differences $(p=0.001)$ were found.

In the analyzed 6-month period, $77.2 \%$ of children from Group 2, 64\% of children from Group 0 and $59.5 \%$ of children from Group $1(\mathrm{p}=0.014)$ needed antibiotic treatment, which proportionally reflects the quantitative distribution of frequency of occurrence of lower respiratory tract infections in the respective studied groups. 9.5\% of children from Group $0,7.6 \%$ of children from Group 1 and $15.7 \%$ of children from Group 2 needed hospitalization for different reasons: Gr2: Gr0 - p=0.04, Gr1: Gr2 - p=0.015.

\section{DISCUSSION}

Nearly half of the studied 3-year-old children lived in families where at least one person smoked. Nearly $1 / 3$ of the children lived in households with a total prohibition of smoking. Most of the parents of those children had higher education. The group of 3-year-olds whose parents reported that smoking was permitted in allocated rooms of their flats (from which the children were absent) included $26.1 \%$ of the subjects. The rest of children, $45.4 \%$, lived in families where no regulations concerning smoking had been established, which indicates that the awareness of the harmful impact of exposure to ETS among parents of the studied children is low, and is ignored by nearly half of the respondents. A study by Jung et al. [13] established the smoking statuses of parents of children aged 6-11 years in Anyang City, Gyeonggi Province, South Korea, proved that $40.9 \%$ of the children were not exposed to smoking at home, $18.5 \%$ were exposed to second-hand smoking and $40.6 \%$ exposed to third-hand smoking (THS) (smoke that lingers after the extinguishing of a cigarette, present in furniture, clothes or hair) [14].

CCR values in the urine of children potentially protected from exposure to ETS (Grl) were similar to values occurring in children whose parents allowed smoking in their presence
(Gr2). Jurado et al. [15] obtained similar results in a study carried out in Granada, Spain, among 3-6-year-old preschool children. The results indicate that smoking in allocated rooms in flats with a small cubic capacity (prevalent among the respondents) did not accomplish the purpose intended by the parents, and did not protect the children from the impact of smoke [16]. Protano et al. showed a clear correlation between cotinine concentration in the urine of the studied children and exposure to tobacco smoke, depending on the habit of tobacco smoking and the number of cigarettes smoked by the parents [17].

The observed discrepancy between the survey outcome and biochemical results might have been caused by dishonesty of the respondents - they may have provided false but socially desirable answers in the questionnaire about regulation of smoking in their households. It seems unlikely that a large group of subjects were exposed to tobacco smoke outside their home, although that possibility must also be considered. Indirect passive smoking (THS) must also be taken into consideration. Its toxic influence is described in detail by Matt et al. [18].

According to Dove et al. [19], the legal restriction of smoking in public places results in a lower cotinine concentration in blood serum of children. Dempsey et al. [20] observed a significant discrepancy between survey data received from parents, reporting that $13 \%$ of the hospitalized children were exposed to ETS, and the fact that cotinine was found in $55 \%$ of blood serum of the studied children. Sabanty et Bróździk [21], who assessed CCR in the urine of elementary schools students in Łódź, Poland, observed that among those exposed to smoke, the CCR value was lower in children who had their own bedrooms. The study concerned older children who could consciously avoid the smoke and ventilate their bedrooms. The 3-year-old children considered in the presented were not able to do so because of their lack of autonomy due their young age.

During 6 months of attending pre-schools, 85\% of the subjects had at least one respiratory tract infection. Some children repeatedly suffered from the same and different infections. The biggest number of sufferers recruited from 
families where ETS exposure was not controlled, whereas the children not exposed to tobacco smoke were the smallest group of sufferers. The difference between those groups, however, was not significant. Irrespective of the studied group, the children most often suffered from acute upper respiratory tract infections. The highest number of recurring infections of that type was observed in children from GR2, but the differences between particular groups were not significant. Acute lower respiratory tract infections also mostly repeated in children from GR2 and least often in GR1. A significant difference between the 2 groups concerned the number of children who had up to 4 lower respiratory tract infections $(p=0.0001)$. It is curious that the children from homes where smoking was prohibited were ill nearly as often as the children from the exposed group, whereas the children who were potentially protected from smoke had the fewest acute lower respiratory tract infections. In that group, however, recurrent otitis media occurred most frequently.

Cook et al. [22] analyzed 50 studies evaluating the relation between exposure to ETS and increased rate of lower respiratory tract infections in young children. The results of 29 publications confirmed a relationship between secondhand smoke and increased morbidity rate of bronchitis, bronchiolitis and pneumonia, as well as an increased number of related stays in hospital. The meta-analysis carried out by Li et al. [23] indicates that there is an increased risk of lower respiratory tract infections in children exposed to ETS, especially in those aged less than 2 tears of age. Złotowska [24] published a study conducted as part of the international study project CESAR (Central European Study of Air pollution and Respiratory Health), which covered children aged 9-11. In it, she noted a statistically significant correlation between exposure to ETS and the occurrence of pneumonia in medical history. Krzywicka et al. [25], having interviewed parents of children hospitalized for respiratory tract infections, observed that more than 3 recurrences of bronchitis and pneumonia within a year occurred in $69.4 \%$ of children aged 2-4 exposed to ETS, and in $21.1 \%$ of children not exposed to second-hand smoke. The statistically significant relationship between second-hand smoke and the rate of acute bronchitis and dysphonia incidents in hospitalized children aged 0-7 was proved by Mania et al. [26].

In the presenyed study, it was found that statistically more children from Gr2 were exposed to ETS before birth due to their mothers and fathers smoking. However, when conducting the study in the groups mentioned in the current study, no relationship was shown between that exposure and the number of respiratory tract infections

Jones et al. [4] concluded that prenatal exposure to ETS significantly increased morbidity of infections, especially of the lower respiratory tract. The risk is still greater with additional exposure to ETS after birth. Baker et al. [27] proved a relationship between mothers who smoked, especially when breast-feeding, and increased risk of lower respiratory illness in the first 3 years of life.

The results of the ISAAC (International Study of Asthma and Allergies in Childhood), carried out in populations of schoolchildren in Poland, Germany, the Netherlands and Switzerland, also did not show any influence of pre-natal second-hand smoke regarding increased occurrence of bronchitis and pneumonia in the studied children in any of the countries [28].
Badeńska \& Czerwionka-Szaflarska [29] proved in their study that $87.3 \%$ of repeatedly hospitalized children were exposed to second-hand smoke at home, and the most frequent reasons for their hospitalization were acute respiratory tract infections and otitis media.

The results of the presented study are consistent with those quoted above regarding the higher number of hospitalizations of children who were not protected from smoke at home, in relation to those who were protected $(\mathrm{p}=0.04)$ and potentially protected $(\mathrm{p}=0.015)$.

\section{CONCLUSIONS}

Exposure to tobacco smoke in the population of 3-year-old children attending public pre-schools in Białystok does not differ significantly from the average exposure estimated in Poland.

3-year-olds who have less educated parents are more exposed to passive smoking at home.

The method of partial limitation of the exposure of children to ETS at home is ineffective

Children living in a home environment polluted with tobacco smoke more often have respiratory tract infections, and significantly more often need antibiotic treatment and hospitalization

\section{Conflict of Interest}

The authors have no financial or other relationships that might lead to a conflict of interest.

\section{REFERENCES}

1. Ruskamp J, Smit H, Rovers M, Hoekstra M, Schilder A, Brunekreef B et al. Neonatal total IgE and respiratory tract infections in children with intrauterine smoke exposure. Arch Dis Child. 2010; 95(6): 427-431.

2. Jones LL, Hashim A, McKeever T, Cook DG, Britton J, Leonardi-Bee J. Parental and household smoking and the increased risk of bronchitis, bronchiolitis and other lower respiratory infections in infancy: systematic review and meta-analysis. Respir Res. 2011; 10(12): 5.

3. Constant C, Sampaio I, Negreiro F, Aguiar P, Silva A, Salgueiro M, Bandeira T. Environmental tobacco smoke (ETS) exposure and respiratory morbidity in school age children.Rev Port Pneumol. 2011; 17(1): 20-26.

4. Wilson KM, Klein JD, Blumkin AK, Gottlieb M, Winickoff JP. Tobaccosmoke exposure in children who live in multiunit housing. Pediatrics 2011; 127(1): 85-92.

5. Public Health Europe http://ec.europa.eu/health/ph_determinants/ life_style/Tobacco/smoke_free_en.htm (access: 2012.10.04).

6. Bartkowiak Z. Harmfulness of second-hand smoke. Otolar Pol. 1995; 49(3): 272-275.

7. Borland R, Young HH, Cummings KM, Hyland A, Anderson S, Fong GT. Determinants and consequences of smoke-free homes: findings from the International Tobacco Control (ITC) Four Country Survey. Tob Control. 2006; 15(Suppl III): iii42-50.

8. Bialystok.pl-Oficjalny portal miejski http://www.bialystok.pl/272dane-statystyczne/default.aspx (access: 2013.12.17) (in Polish).

9. Główny Urząd Statystyczny, 2009.p.29 http://www.stat.gov.pl/cps/rde/ xbcr/gus/OZ_miasta_wojewodzkie_nr_17.pdf. (access: 2013.11.28) (in Polish).

10. Główny Urząd Statystyczny, Bank Danych Lokalnych, 2013 http:// www.stat.gov.pl/bdl/app/dane_podgrup.display?p_id=38486\&p_ token $=0.8581112293911363$ (access: 2013.12 .17 ) (in polish)

11. Wojewódzki Inspektorat Ochrony Środowiska w Białymstoku, 2013.p.19-20 http://www.wios.bialystok.pl/pdf/raport2011-2012.pdf (accessed: 2013.12.02) (in Polish).

12. Benowitz NL. Cotinine as a biomarker of environmental tobacco smoke exposure. Epidem Rev. 1996; 18: 188-204. 
13. Jung JW, Ju YS, Kang HR. Association between parental smoking behavior and children's respiratory morbidity: 5 -year study in an urban city of South Korea. Pediatr Pulmonol. 2012; 47(4): 338-345.

14. Protano C, Vitali M. The new danger of thirdhand smoke: why passive smoking does not stop at secondhand smoke. Environ Health Perspect. 2011; 119(10): A422. doi:10.1289/ehp.11039563.

15. Jurado D, Munoz C, De Dios Luna J, Fernandez-Crehuet $M$. Environmental tobacco smoke exposure in children: parental perception of smokiness at home and other factors associated with urinary cotinine in preschool children. J Expo Anal Environ Epidemiol. 2004; 14: 330-336.doi:1038/sj. Jea.7500329.

16. Protano C, Andreoli R, Manini P, Guidotti M, Vitali M. A tobaccorelated carcinogen: assessing the impact of smoking behaviours of cohabitans on benzene exposure in children. Tob Control. 2012; 21: 325-329.

17. Protano C, Andreoli R, Manini P, Matteo V. How home-smokong habits affect children: a cross-sectional study using urinary cotinine measurement in Italy. Int J Public Health. 2012; 57: 885-892. doi:10.1007/ s00038-012-0354-0b.

18. Matt GE, Quintana PJ, Destaillats H, Gundel LA, Sleiman M, Singer $\mathrm{BC}$ et al. Thirdhand tobacco smoke: emerging evidence and arguments for a multidisciplinary research agenda. Environ Health Perspect. 2011; 119(9): 1218-1226

19. Dove MS, Dockery DW, Connolly GN. Smoke-free air laws and secondhand smoke exposure among nonsmoking youth. Pediatrics. 2010; 126(1): 80-87.

20. Dempsey DA, Meyers MJ, Oh SS, Nguyen EA, Fuentes-Afflick E, Wu $\mathrm{AH}$, et al. Determination of Tobacco Smoke Exposure by Plasma Cotinine Levels in Infants and Children Attending Urban Public Hospital Clinics. Arch Pediatr Adolesc Med. 2012; 166(9): 851-856. doi: 10.1001/archpediatrics.2012.170.
21. Sabanty W, Bróździk H. Selected health indicators and cotinine concentrations in urine of boys attending Łódź elementary schools exposed to the impact of tobacco smoke at home. Cotinine as an indicator of exposure to the impact of tobacco smoke (second-hand smoking). Prz Pediatr. 2005; 34(1): 55-57.

22. Cook DG, Strachan DP, Carey IM. Health effects of passive smoking. 9. Parental smoking and spirometric indices in children.Thorax. 1998; 53(10): 884-893.

23. Li JS, Peat JK, Xuan W, Berry G. Meta-analysis on the association between environmental tobacco smoke (ETS) exposure and the prevalence of lower respiratory tract infection in early childhood. Pediatr Pulmonol. 1999; 27(1): 5-13.

24. Złotowska R. Second-hand smoking and respiratory system diseases in young elementary schoolchildren. Med Środow. 2001; 4(2): 25-32.

25. Krzywiecka M, Obuchowicz A, Bukowska C, Wielkoszyński T, Swietochowska-Chechlińska A, Kula-Gradzik J. Evaluation of infants and younger children passive smoking at home and prevalence of their lower respiratory tract infectious. Przegl Lek. 2006; 63(10): 827-830.

26. Mania M, Przybysz A, Kurylak A. Passive smoking and frequency of occurrence of disease symptoms in the respiratory system in children aged 0-7. Przegl Lek. 2006; 63(10): 831-833.

27. Baker RJ, Hertz-Picciotto I, Dostál M, Keller JA, Nozicka J, Kotesovec F, et al. Coal home heating and environmental tobacco smoke in relation to lower respiratory illness in Czech children, from birth to 3 years of age. Environ Health Perspect. 2006; 114(7): 1126-1132.

28. Złotowska R, Pattenden S, Heinrich J, Nehring U, Holk G, Jansen N et al. Atopy, second-hand smoking and the condition of respiratory system in schoolchildren. Acta Pneumonol Allergol Pediatr. 2006; 9(1): 10-15.

29. Badeńska B, Czerwionka-Szaflarska M. Analysis of results of exposure to passive smoking in pre- and postnatal period in children - authors' own observations. Prz Pediatr. 2001; 32: 3-5. 